\title{
ANDRESEN, Sophia de Mello Breyner. Coral e outros poemas. Org. Eucanaã Ferraz. 1. ed. São Paulo: Companhia das Letras, 2018.
}

Sofia Glória de Almeida Soares

Universidade Federal do Rio de Janeiro (UFRJ), Rio de Janeiro, Rio de Janeiro / Brasil sofiagloria11@gmail.com

Data de submissão: $1^{\circ}$ de novembro de 2018

Data de aprovação: 9 de janeiro de 2019

Gosto de pensar o processo de organização e montagem de uma antologia de poemas traçando um paralelo entre esse trabalho e o do curador de exposições de arte em museus. Uma antologia é e sempre será um recorte ao redor da obra de determinado autor, de um grupo de autores, de uma época, de um tema. $O$ fato é que sempre estaremos lidando com escolhas realizadas por outro leitor que não eu. Em ambos os contextos, a proposição do percurso deixa impressas marcas de leitura da(s) obra(s) em questão, meios de apreensão e alcance do objeto artístico. Analisar a ampla obra poética de Sophia de Mello Breyner Andresen e eleger alguns textos em detrimento de outros não é tarefa simples, seja pelo volume da produção, seja por sua complexidade. Nesse processo de montagem e crítica, as ausências são tão plenas de significado quanto as presenças, numa espécie de leitura pelo viés da falta.

A voz. O mar. O ritmo silabado. Voz como instância moldada pela cultura e tudo o que ela comporta, mas também e sobretudo, voz como encontro com sua natureza primeira - o som - material, físico, mensurável, vibração de ondas (impulso e repouso). O mar: movimentação incessante e rítmica, ir e vir, continuidade e quebra, serenidade e fúria, murmúrio e grito, encontro e separação em medida exata, dinâmica poética de sílabas. 
Esses parecem ser os eixos fundamentais que circundam o itinerário desenhado por Eucanaã Ferraz na antologia Coral e outros poemas, de Sophia de Mello Breyner Andresen, lançada em 2018 pela Companhia das Letras. Nela, o autor de Escuta acentua a concretude dessa poesia, concretude assente no fato de ela existir primeiramente enquanto voz. "A poesia de Sophia de Mello Breyner Andresen está entre nós, concreta e viva. É uma voz, vem de uma natureza - um corpo - que nunca se repete" (FERRAZ, 2018, p. 17), lê-se no início de "Breve percurso rente ao mar", texto de apresentação da antologia que traça de modo claro e conciso, justo (diria talvez a poeta), um panorama cíclico e harmonioso sem deixar de ressaltar os relevos característicos de cada livro. Encarar essa poesia enquanto voz funda, por consequência, uma poética também da escuta, enunciada por Sophia em versos como "Tudo neles se cala pra escutar", do poema "Homens à beira-mar" (ANDRESEN, 2018, p. 57), e "Gosto de ouvir o português do Brasil [...] / Gosto de ouvir a palavra com suas sílabas todas [...]", de "Poema de Helena Lanari" (ANDRESEN, 2018 , p. 224). Também poderia figurar nesse hall o poema "Escuto" (ANDRESEN, 2015, p. 516), de Geografia, que não se apresenta entre os selecionados na antologia.

É inegável que observar a exaltação e a forte presença do mar na poética de Sophia (utilizando a acepção da palavra apresentada por Eucanaã Ferraz ${ }^{1}$ ), não é contribuição original para a fortuna crítica da autora, já que ao longo dos anos muitos trabalhos foram produzidos nesse sentido. Porém, chamo a atenção para o modo como Ferraz evoca a imagem do mar nessa obra: além de tema, ela atua como procedimento de escrita. Em outras palavras, trata-se de enxergar o traço cíclico aí presente à imagem das marés. No decorrer dessa trajetória poética nota-se uma incessante revisitação de temas, formas, personagens e lugares caros a essa poesia. O respeito a esse traço de recorrência temática, por exemplo, garante a manutenção em Coral e outros poemas do tom harmônico presente no volume completo da obra poética. A título de ilustração, note-se o número de poemas que tematizam a escrita, as cidades, ou que apresentam como personagens Orfeu e Eurídice.

1 “'...] tomando-se o termo 'poética' como um conjunto de valores de largo alcance, composto por uma personalidade em que não se separam autor e obra [...]" (FERRAZ, 2018, p. 28). 
No texto de abertura, Eucanaã Ferraz ressalta um dado importante: essa é a segunda antologia de poemas da autora portuguesa publicada no Brasil. A primeira, também publicada pela Companhia das Letras, em 2004, foi organizada por Vilma Arêas. A reunião mais recente oferece ao leitor a versão integral do livro $O$ Cristo cigano, além de incluir textos dos dois livros seguintes, Musa e O búzio de Cós e outros poemas que não figuram naquela organizada por Arêas. Outra diferença significativa entre os trabalhos é a presença de alguns dos "Poemas esparsos" e inéditos na antologia de 2018. A ausência dos referidos poemas na reunião de 2004 é justificada pelo fato de que esses textos vieram a público em 2010 (Caminho) e 2015 (Assírio \& Alvim), respectivamente. ${ }^{2}$ Por sua vez, os textos publicados como "Artes poéticas" figuram em ambas as coletâneas com feições distintas. Em Coral e outros poemas há uma seção exclusiva que reúne os cinco textos assim denominados. Poemas escolhidos é fiel à ordem das edições autônomas e mantém cada uma das "Artes poéticas" na sequência em que aparecem em meio aos poemas de cada livro.

Diante do esplendor e do espanto desse universo, o leitor de Sophia de Mello Breyner Andresen atravessa o deserto do mundo, em meio às ruínas e à morte, na certeza de nunca ter as mãos vazias.

\section{Referências}

ANDRESEN, Sophia de Mello Breyner. Obra poética. Ed. Carlos Mendes de Sousa. Porto: Assírio \& Alvim, 2015.

ANDRESEN, Sophia de Mello Breyner. Poemas escolhidos. Org. Vilma Arêas. São Paulo: Companhia das Letras, 2004.

ANDRESEN, Sophia de Mello Breyner. Coral e outros poemas. Org. Eucanaã Ferraz. 1. ed. São Paulo: Companhia das Letras, 2018.

FERRAZ, Eucanaã. Breve percurso rente ao mar. In: ANDRESEN, Sophia de Mello Breyner. Coral e outros poemas. Org. Eucanaã Ferraz. 1. ed. São Paulo: Companhia das Letras, 2018. p. 17-42.

${ }^{2}$ Cf. Nota de edição de Carlos Mendes de Sousa (ANDRESEN, 2015, p. 53-55). 